\title{
Article \\ Mercury Uptake and Transport by Plants in Aquatic Environments: A Meta-Analysis
}

\author{
Yuanzhang Ma ${ }^{1}$, Guoyu Wang ${ }^{2}$, Yuanyuan Wang ${ }^{1}$, Wei Dai ${ }^{1, *}$ and Yaning Luan ${ }^{1, *}$ (1) \\ 1 College of Forestry, Beijing Forestry University, Beijing 100083, China; yuan0305@bjfu.edu.cn (Y.M.); \\ wangyyuan@bjfu.edu.cn (Y.W.) \\ 2 China Urban Construction Design \& Research Institute Co., Ltd., Beijing 100120, China; wangguoyu@cucd.cn \\ * Correspondence: daiwei1@bjfu.edu.cn (W.D.); luanyaning@bjfu.edu.cn (Y.L.); Tel.: +86-10-6233-6082 (Y.L.)
}

Citation: Ma, Y.; Wang, G.; Wang, Y.; Dai, W.; Luan, Y. Mercury Uptake and Transport by Plants in Aquatic Environments: A Meta-Analysis. Appl. Sci. 2021, 11, 8829. https:// doi.org/10.3390/app11198829

Academic Editor: Vincent Perrot

Received: 8 August 2021

Accepted: 22 September 2021

Published: 23 September 2021

Publisher's Note: MDPI stays neutral with regard to jurisdictional claims in published maps and institutional affiliations.

Copyright: (c) 2021 by the authors. Licensee MDPI, Basel, Switzerland. This article is an open access article distributed under the terms and conditions of the Creative Commons Attribution (CC BY) license (https:// creativecommons.org/licenses/by/ $4.0 /)$.

\begin{abstract}
The use of phytoremediation technology to remove heavy metal ions from aquatic environments or reduce their toxicity offers the possibility of restoring the ecological environment of polluted water bodies. Based on available literature on heavy metal absorption by aquatic plants, we conducted a meta-analysis to study the absorptive capacities of different plants as well as the factors that influence their Hg-absorption performance. Seventeen plant families, including Araceae, Haloragaceae, Hydrocharitaceae, and Poaceae, have a strong Hg-absorption capacity. The root systems of aquatic plants belonging to these families are primarily responsible for this remediation function, and only a limited proportion of $\mathrm{Hg}^{+}$that enters a plant via the root system is transferred to other plant organs. Additionally, the diversity of plant life habits (e.g., floating, submerged, and emergent) and the water $\mathrm{pH}$ significantly influence the ability of plants to absorb $\mathrm{Hg}$. It is expected that this study will provide a reference for the cultivation of aquatic plants for restoring the ecological environment of $\mathrm{Hg}$-polluted water bodies.
\end{abstract}

Keywords: phytoremediation; meta-analysis; mercury; absorptive capacity; bioconcentration factor

\section{Introduction}

Heavy metals are some of the deadliest pollutants and their concentrations in the environment have considerably increased owing to human activities [1]. Lee [2] and Ozden et al. [3] have shown that five potentially toxic heavy metals, namely arsenic (As), cadmium $(\mathrm{Cd})$, chromium $(\mathrm{Cr})$, mercury $(\mathrm{Hg})$, and lead $(\mathrm{Pb})$, are the most dangerous and persistent pollutants. $\mathrm{Hg}$, which has been listed as a global pollutant by the United Nations Environment Program, can be transported through air in a gaseous form at room temperature. When $\mathrm{Hg}$ enters water, it undergoes methylation, produces highly toxic methylmercury, and accumulates in food chains; this results in an increase in its concentration, with increasing trophic levels [4]. Studies have shown that $\mathrm{Hg}$ can reduce the photosynthetic rate of algae and inhibit cell division [5]. It has also been observed that water bodies with $\mathrm{Hg}$ concentrations of $0.003 \mathrm{~g} / \mathrm{L}$ exert a toxic effect on goldfish [6]. Additionally, owing to the escalating nature of toxins in food chains, $\mathrm{Hg}$ is accumulating at an exponential rate in the internal organs of mammals [7]. When this bioaccumulated $\mathrm{Hg}$ reaches humans, it can cause brain-, heart-, kidney-, and lung-related diseases, and can even contribute to chromosome breaks [8,9].

Conventional methods for remediating heavy metal pollution in water, such as ion exchange, precipitation, and reverse osmosis, are not cost-effective and can adversely affect aquatic ecosystems [10]. Fortunately, phytoremediation technology, which focuses on the ability of plant roots, stems, and leaves to absorb and accumulate heavy metal elements, has been extensively investigated as a practical alternative to conventional methods [11]. Certain floating, submerged, and emergent plants have been identified as potential heavy metal accumulators [12-15]. These aquatic plants generally absorb heavy metals via chelation and compartmentalization and, thus, demonstrate tolerance to high 
heavy metal concentrations [16]. Specifically, glutathione and chelating peptides derived from it play an important role in plant-assisted detoxification by binding to heavy metals and reducing free heavy metal ions in plant cells [17].

Several researchers have conducted experiments on the remediating effect of aquatic plants on heavy metal pollution; some review articles have also qualitatively described the heavy metal absorption mechanism of these plants [10-16]. However, systematic and statistical methods for the comprehensive evaluation of the $\mathrm{Hg}$ absorption capacity of aquatic plants are still lacking. Furthermore, the absorption capacities of aquatic plants for different heavy metals in polluted water are different, even when the influencing factors are the same [18]. Therefore, it is necessary to comprehensively and quantitatively analyze the $\mathrm{Hg}$ absorption and transport capacities of different types of aquatic plants that are exposed to different $\mathrm{Hg}$ concentrations and various environmental factors.

Meta-analysis is a quantitative statistical analysis method that includes point estimation and bias-corrected $95 \%$ confidence interval (CI), other central trends, as well as accuracy [19]. It can be used to synthesize and compare research results on a specific research topic and also summarize the overall rules of the topic $[19,20]$. Meta-analytical methods have been increasingly used in the study of ecological problems [20]. Therefore, in this study, meta-analysis was used to quantitatively analyze (1) the Hg absorption capacity of different plants, (2) the absorption of $\mathrm{Hg}$ ions in plant roots and their transportation throughout the plants, and (3) the effects of different influencing factors on the heavy metal absorption capacities of the plants.

\section{Materials and Methods}

\subsection{Literature Selection}

Relevant studies corresponding to the 1991-2021 period were collected from the Web of Science, Engineering Village, Wiley Online Library, and China National Knowledge Infrastructure (CNKI). The search keywords were phytoremediation, aquatic plants, wetland plants, bioaccumulation, heavy metals, and $\mathrm{Hg}$. The obtained articles were further screened for studies that met the following criteria: (1) the focus of the research was an aquatic plant that absorbs $\mathrm{Hg}$; (2) the study contained clear experimental steps and data (sample size, mean, and standard deviation); and (3) no compounds that could influence the $\mathrm{Hg}$ absorption capacity of the plants were added during the study.

Thus, 30 articles, 18 field experiments, and 12 laboratory simulation experiments, constituting a total of 197 observation groups, were selected. Furthermore, the researched plants, which belonged to 33 families and 74 species, were categorized as floating, submerged, emergent, and wetland plants (Figure 1), to facilitate data analysis.

\subsection{Data Processing}

Excel 2021 (Microsoft Office) was used to establish a database of the selected studies. The data entry for each study included the name of the first author, year of publication, experimental site, plant species, plant habitat, $\mathrm{pH}$, sample size, mean, and standard deviation between the control and experimental groups. If the study only presented the standard error or the maximum, minimum, and median values, the standard deviation was calculated using the following formulae:

$$
\begin{gathered}
\mathrm{SD}=\mathrm{SE} \times \sqrt{\mathrm{n}} \\
\overline{\mathrm{X}}=\frac{\mathrm{a}+2 \mathrm{~m}+\mathrm{b}}{4} \\
\mathrm{SD}=\sqrt{\frac{4 \overline{\mathrm{X}}^{2}+(b-a)^{2}}{12}}
\end{gathered}
$$

where $\mathrm{n}$ represents the sample size; $\mathrm{a}$ and $\mathrm{b}$ are the maximum and minimum values, respectively; $\mathrm{m}$ is the median; $\overline{\mathrm{X}}$ is the mean; and SD and SE are the standard deviation 
and standard error, respectively [51]. All data provided in a chart format were extracted using Getdata Graph Digitizer 2.24 (support@getdata-graph-digitizer.com).

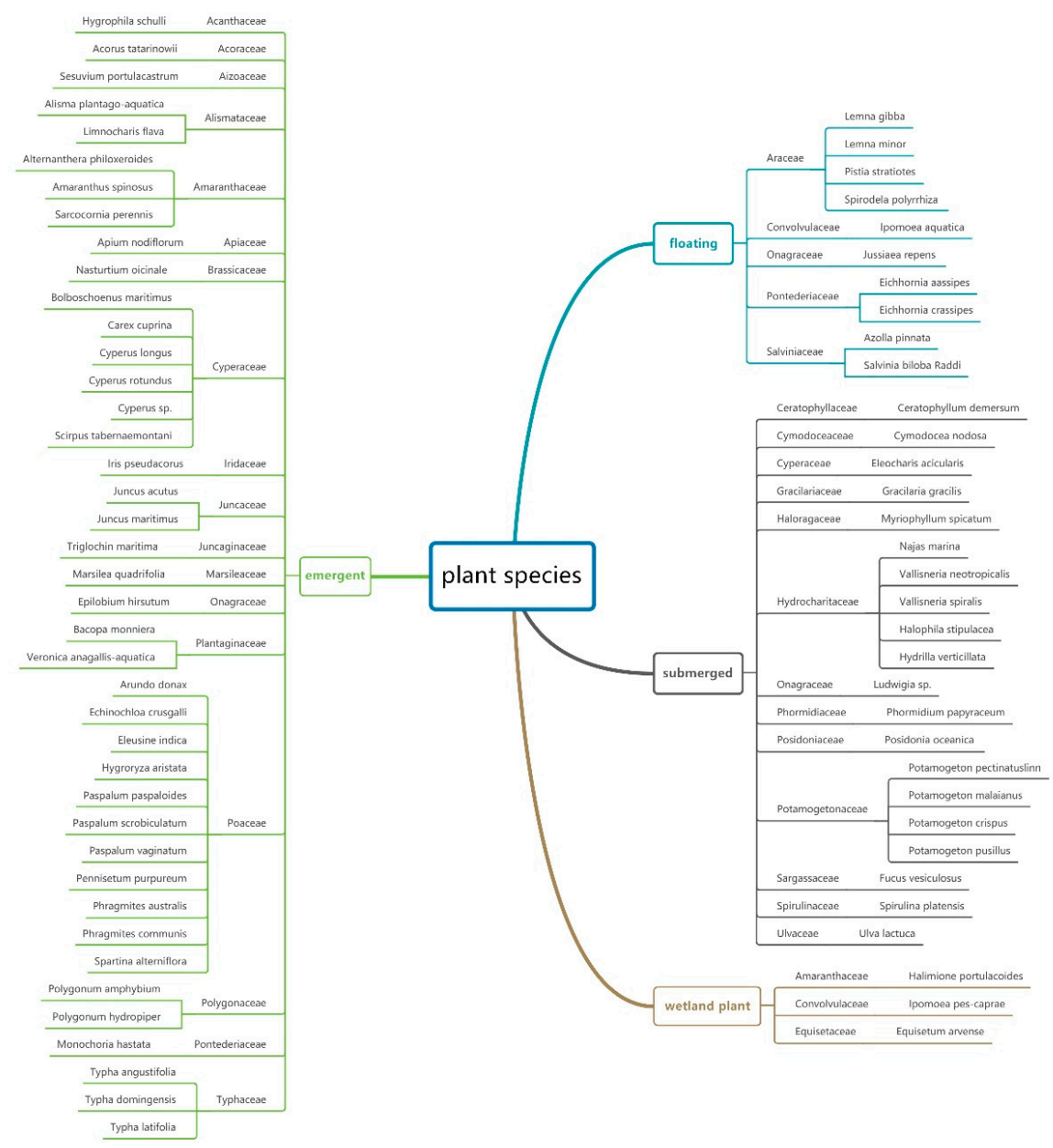

Figure 1. Plant species classification based on the Angiosperm Phylogeny Group III system [21-50].

The data used in this study were obtained from independent experiments. For each study, the data were categorized into a control group and an experimental group. Effect size (ES) was determined based on the response ratio (R), and for each group of observations, the corresponding $R$ and its variance $(V)$ were calculated. The formulae used for these calculations were as follows:

$$
\begin{gathered}
\mathrm{ES}=\ln (\mathrm{R})=\ln \left(\frac{\overline{\mathrm{Xe}}}{\overline{\mathrm{Xc}_{\mathrm{c}}}}\right) \\
\mathrm{V}=\frac{\mathrm{Se}^{2}}{\mathrm{ne} \overline{\mathrm{Xe}}^{2}}+\frac{\mathrm{Sc}^{2}}{\mathrm{nc} \overline{\mathrm{Xc}}^{2}}
\end{gathered}
$$

where $\overline{\mathrm{Xe}}$ and $\overline{\mathrm{X}_{\mathrm{c}}}$ represent the means of the experimental and control groups, respectively; ne and nc represent the number of samples in the experimental and control groups, respectively; and Se and Sc represent the standard deviations of the experimental and control groups, respectively [52]. The average effect of all observations can be estimated using the following equations:

$$
\begin{gathered}
\mathrm{W}=\frac{1}{\mathrm{~V}} \\
\overline{\ln (\mathrm{R})}=\frac{\sum_{\mathrm{i}} \mathrm{Wiln}(\mathrm{Ri})}{\sum_{\mathrm{i}} \mathrm{Wi}}
\end{gathered}
$$


where $\mathrm{W}$ represents the weighted factor of the influence of each observation and Ri and Wi represent the values of $\mathrm{R}$ and $\mathrm{W}$ of the ith observation, respectively [53].

The estimation of $\mathrm{R}$ depended on the context of each examined study. For example, when the experimental and control groups in a particular study represented the $\mathrm{Hg}$ concentration in aquatic plants and those in water, respectively, $\mathrm{R}$ was obtained as the logarithm of the biological concentration factor (BCF), which is a measure of the ability of the plants to absorb heavy metals from the environment. When the experimental and control groups represented the $\mathrm{Hg}$ concentration in plant roots and those in water or sediments, respectively, R was obtained as the logarithm of the biological accumulation factor (BAF), whereas when the experimental and control groups represented the $\mathrm{Hg}$ concentration in plant roots and those in the aboveground plant parts, respectively, $\mathrm{R}$ was obtained as the logarithm of the translocation factor (TF). Therefore, we were able to derive different conclusions by interpreting the different estimations of $\mathrm{R}$.

\subsection{Statistical Analysis}

The ecological meta-analysis software Meta Win2.1 [54] was used to calculate the overall average effect for each group of observations. Based on 9999 iterations for each grouping category, $95 \%$ bootstrapped CIs were generated using a random-effect model [53]. If the $95 \%$ CI did not overlap with the critical value, it implied that there was a significant difference between the selected experimental group and the control group [55]. The overall heterogeneity of the effects in each study was determined using a q-test, and the results of the statistical processing were considered statistically significant at $p<0.05$.

\subsection{Publication Bias}

Publication bias refers to the phenomenon where studies with statistically significant results are more likely to be accepted and published than those without statistically significant results [56]. Considering this influence, publication bias was assessed using the methods described by Rosenberg et al. [54], namely, statistical (Begg's and Egger's tests), graphical (funnel plot), and "trim-and-fill" methods. Thus, publication bias was eliminated or corrected. When the fail-safe number was higher than the critical value $(5 n+10$, where $n$ is the number of groups of observed values in the literature), the conclusion was considered reliable and greatly unaffected by publication bias [52,57].

\section{Results and Discussion}

\subsection{BCF of $\mathrm{Hg}$ in Plants}

Fifty-three plant species belonging to 19 families $(n=117)$ that were monitored more than twice in a given study were selected from the database, and their ability to accumulate $\mathrm{Hg}$ from water was analyzed. The effect sizes (ln BCF) of the same family plants from the same aquatic habitat were combined to calculate the mean and $95 \% \mathrm{CI}$ values. The details were inferred from the simplified forest plot shown in Figure 2. The total average effect size of all species was significantly greater than zero (Laboratory: mean $=8.155$, CI: 7.042-9.389; Lake: mean $=3.928$, CI: 2.935-4.945; River: mean = 7.774, CI: 6.735-8.739; Sea: mean $=8.833$, CI: 8.163-9.448). Furthermore, among the 19 families, Araceae in the laboratory showed the highest average effect size (mean $=11.847$, CI: $9.277-14.264)$, whereas Onagraceae in the lake showed the lowest value (mean $=-0.219, \mathrm{CI}:-0.329--0.113$ ). Additionally, the average effect size of the other 16 families (Cymodoceacea, Cyperaceae, Gracilariaceae, Haloragaceae, Hydrocharitaceae, Iridaceae, Juncaceae, Plantaginaceae, Poaceae, Polygonaceae, Pontederiaceae, Posidoniaceae, Potamogetonaceae, Salviniaceae, Typhaceae, and Ulvaceae) was significantly greater than zero. Therefore, 17 of the examined plant families were found to significantly absorb $\mathrm{Hg}$ from water. 


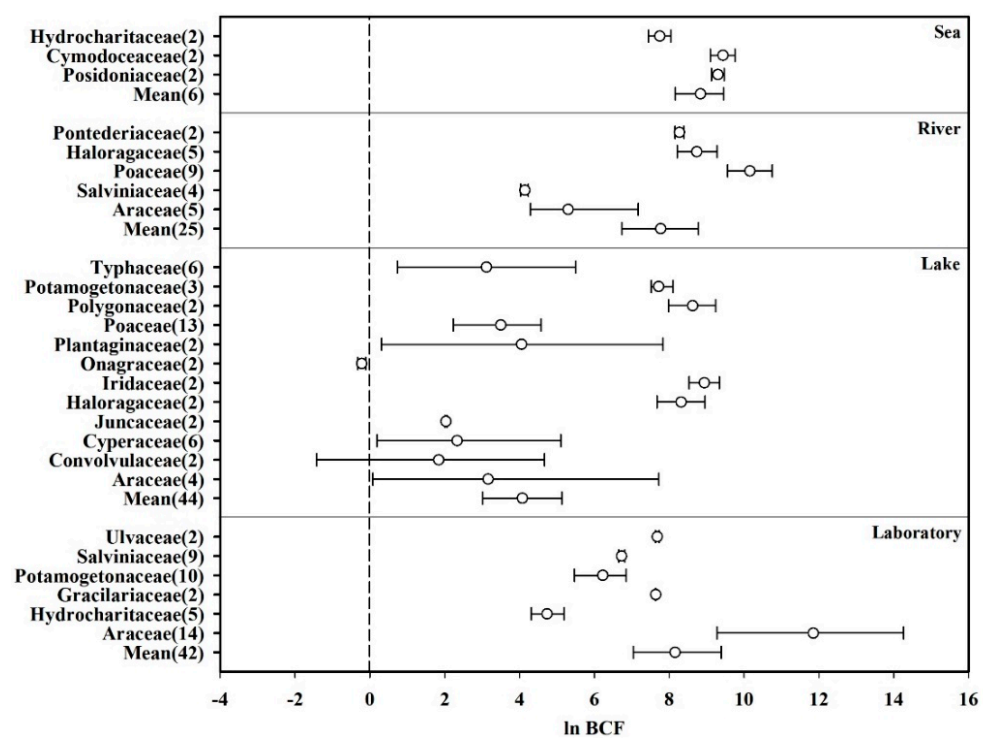

Figure 2. Biological concentration factors (BCFs) of plants based on their families, presented as the mean effect size and 95\% CI. The numerals after the family names represent the number of observations. "Mean" indicates the overall effect considering all families.

As they grow, aquatic plants absorb nutrients from their surrounding environment. Furthermore, based on their importance with respect to plant growth, heavy metals in the environment are classified as essential and non-essential elements. The essential elements (e.g., $\mathrm{Fe}, \mathrm{Zn}$, and $\mathrm{Cu}$ ) can enter plants through transporters on the cell membrane surface, whereas the non-essential elements (e.g., $\mathrm{Hg}, \mathrm{Cd}$, and $\mathrm{Pb}$ ) can enter plants by binding to carbonyl uronic acid [58]. $\mathrm{Hg}$ can inhibit seed germination, reduce root and stem biomass, and retard plant growth $[58,59]$. Thus, to cope with the stress induced by heavy metals in the environment, plants utilize a variety of protection mechanisms, such as root retention, cell wall precipitation, and enzyme system protection [59]; these not only protect plants from $\mathrm{Hg}$ toxicity but also enable them to accumulate large amounts of $\mathrm{Hg}$. This ultimately leads to the hyperaccumulation of $\mathrm{Hg}$ in aquatic environments. Furthermore, the differences in the heavy metal absorption capacities of different plants may be due to the differences in the number and properties of metal-binding sites on the surfaces of plant cells [60].

\subsection{BAF of $\mathrm{Hg}$ in Roots}

The root BAF of the plants was divided into two categories, which corresponded to $\mathrm{Hg}$ uptake from water and that from sediments. Based on the existing data, the effect sizes (ln BAF) of plants belonging to the same family were combined for water (13 families, $n=62$ ) and sediment (14 families, $n=61$ ) to independently calculate the mean and $95 \% \mathrm{CI}$ values. The total effect size of the plants for $\mathrm{Hg}$ absorption from water via the roots (mean $=4.999$, CI: 4.186-5.772) and the average effect size of the plants in each family were significantly greater than zero. Additionally, the effect size of the Cymodoceaceae root system was the highest (mean $=8.709, \mathrm{CI}: 8.389-9.028$ ), whereas among the 13 families in the water uptake category, only Onagraceae and Plantaginaceae roots did not significantly accumulate $\mathrm{Hg}$ from the water (Figure 3a). Regarding $\mathrm{Hg}$ absorption from sediments, the total effect size of the plants was less than zero (mean $=-0.591, \mathrm{CI}$ : $-1.248-0.014$ ), and only the average effect sizes of Cymodoceaceae (mean $=0.556$, CI: 0.201-0.916), Hydrocharitaceae (mean $=0.622$, CI: 0.550-0.693), and Posidoniaceae (mean $=0.372$, CI: $0.182-0.560)$ were greater than zero, indicating that these families significantly absorbed $\mathrm{Hg}$ from sediments (Figure 3b). 


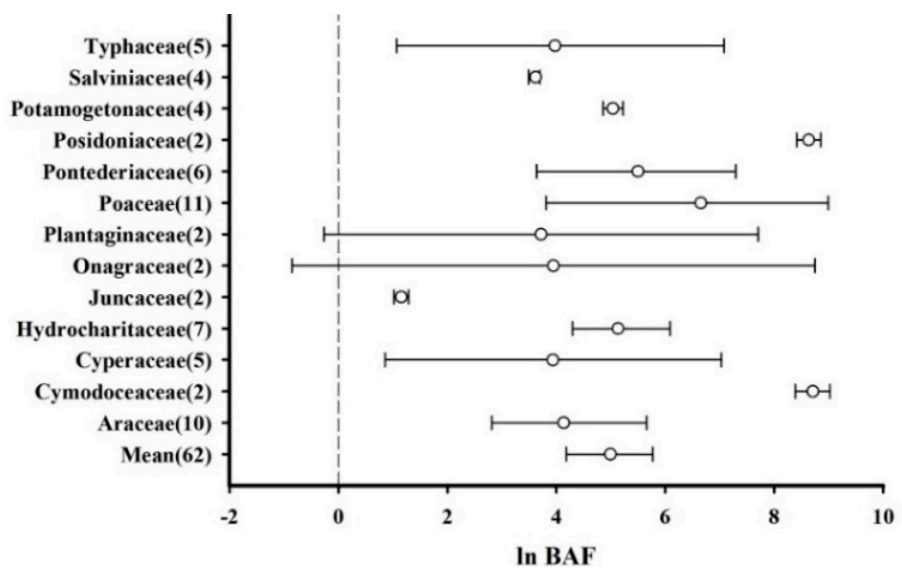

(a)

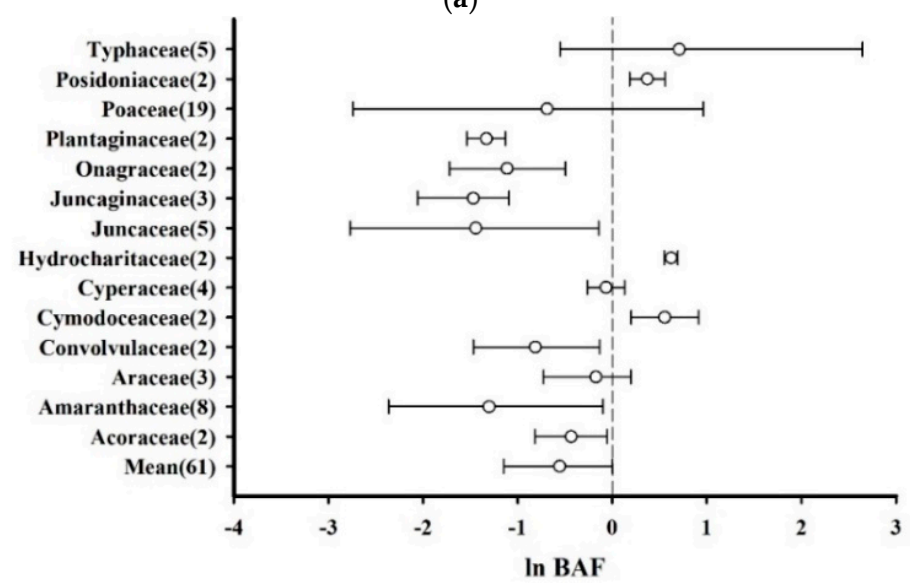

(b)

Figure 3. Biological accumulation factors (BAFs) of plant roots based on families, presented as the mean effect size and 95\% CI. (a) Absorption of $\mathrm{Hg}$ from water by plant roots. (b) Absorption of $\mathrm{Hg}$ from sediments by plant roots. The numerals after the family names represent the number of observations. "Mean" indicates the overall effect considering all families.

In this analysis, $\mathrm{R}$ (ln BAF) represents the ability of plant roots to absorb $\mathrm{Hg}$ from the aquatic environment. During the process of plant growth, root exudates (e.g., macromolecular compound iron carriers, complexin, low-molecular-weight compounds, $\mathrm{H}_{2} \mathrm{CO}_{3}$, and organic acids) affect the solubility and bioavailability of heavy metal ions, owing to their influence on rhizosphere acidification, precipitation, chelation, and redox reactions [61]. Furthermore, owing to natural selection, plants that grow in polluted waters show a certain level of tolerance toward heavy metals in the environment. As the plant organ that is primarily responsible for nutrient absorption, the roots play an important role in the absorption and enrichment of heavy metals (Figure 3a). However, numerous heavy metals accumulate in sediments via precipitation and absorption [62]. Therefore, this analysis can only be used as a reference to compare the $\mathrm{Hg}$ uptake ability of different plant roots from the same environment.

\subsection{TF for $\mathrm{Hg}$ in Plants}

The effect sizes (ln TF) of plants belonging to the same family were combined to calculate mean and 95\% CI values. In this regard, 17 plant families were included in the meta-analysis, and a simplified forest plot was drawn (Figure 4). It was observed that the total average effect size considering all the species was less than zero (mean $=-0.278$, CI: $-0.515--0.043)$, indicating that for most plants, the roots accumulated more $\mathrm{Hg}$ than the aboveground parts. Specifically, the effect sizes corresponding to Cymodoceaceae $($ mean $=0.061$, CI: 0.045-0.077) and Potamogetonaceae (mean = 1.986, CI: 1.704-2.206) were 
significantly greater than zero, indicating that these plants accumulated more $\mathrm{Hg}$ in their aboveground parts relative to their roots. There were no significant differences between the $\mathrm{Hg}$ accumulation capacities of the roots and aboveground parts of Acoraceae, Cyperaceae, Juncaginaceae, Juncaceae, Onagraceae, Poaceae, Posidoniaceae, and Typhaceae plants. However, $\mathrm{Hg}$ accumulation in the roots of Amaranthaceae, Araceae, Convolvulaceae, Hydrocharitaceae, Plantaginaceae, Pontederiaceae, and Salviniaceae was considerably higher than that in their aboveground parts.

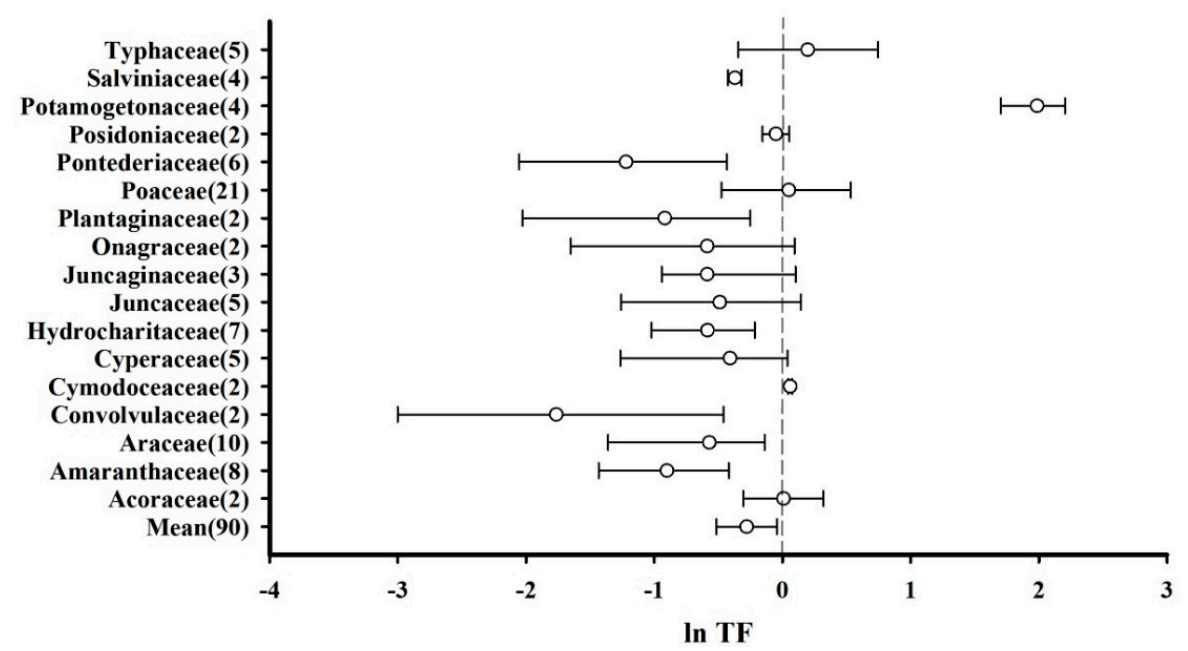

Figure 4. Translocation factors (TFs) of plants based on their families presented as the mean effect size and $95 \%$ CI. The numerals after the family names represent the number of observations. "Mean" indicates the overall effect considering all the plant families.

The diverse differences that exist between plants and changes in environmental conditions may lead to different heavy metal ion transfer coefficients between the roots and aboveground parts of plants $[63,64]$. After entering the plant root, $\mathrm{Hg}^{+}$is either stored in the root tissue or it continues to move upward [65]. For this upward transportation to continue, $\mathrm{Hg}^{+}$needs to be moved from the root symplast to the xylem apoplast $[64,65]$. During this process, most $\mathrm{Hg}^{+}$remains in the root cell wall given that the plant cell wall can precipitate heavy metal ions [63]. Furthermore, negatively charged heavy metal ions have greater mobility, whereas positively charged heavy metal ions tend to accumulate on the negatively charged root surface [66]. Therefore, the transfer of absorbed $\mathrm{Hg}$ by roots to other plant organs is difficult [67].

\subsection{Influencing Factors}

Araceae, Cyperaceae, Haloragaceae, Poaceae, Pontederiaceae, and Typhaceae plants, with a high number of observations, were used to evaluate the levels of $\mathrm{Hg}$ in water, sediments, and plants (Figure 5). The results indicated that the $\mathrm{Hg}$ concentration in plants was slightly higher than that in the sediments and significantly higher than that in water bodies. These observations suggests that sediments in water strongly absorb Hg. Overall, Figures 2-4 indicate that most of the $\mathrm{Hg}$ absorbed by the stems and leaves of aquatic plants is directly sourced from water. Although the absorption capacities of these plant parts are weaker than that of the roots, they play an important role in reducing the $\mathrm{Hg}$ concentration in water. Additionally, $\mathrm{Hg}$ derived from water enters plant leaves and stems via complexation, ion exchange, and physical adsorption, after which it is stored in plant cell walls owing to biosorption [68]. 


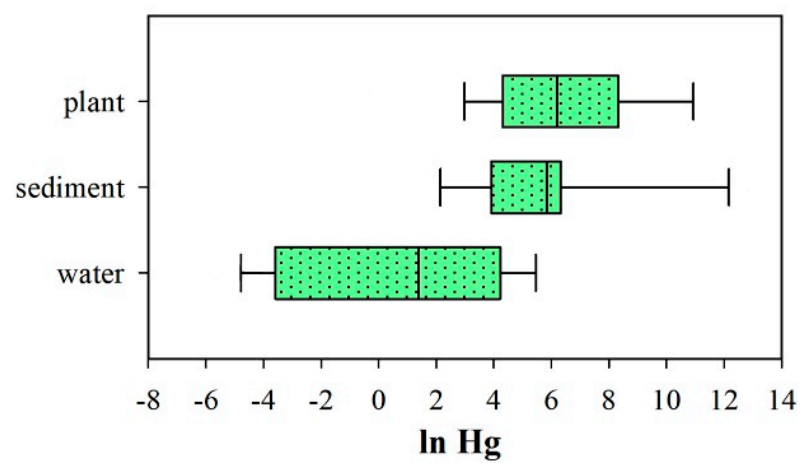

Figure 5. Heavy metal concentrations in water, sediments, and plants.

\subsubsection{Plant Organs}

To express the ability of different plant organs to accumulate $\mathrm{Hg}$ from the environment, the corresponding effect sizes of the organs of each plant were combined to calculate mean and 95\% CI values. Details in this regard are shown in the forest plot below (Figure 6, plant organs). The $\mathrm{Hg}$ concentration in plant roots, stems, and leaves were significantly higher than that in water, but significantly lower than that in sediments. Furthermore, the roots showed a higher $\mathrm{Hg}$ accumulation capacity than the stems and leaves; the average effect sizes in water and sediments were 4.716 and -0.696 , respectively. The plant leaves demonstrated the weakest ability to accumulate $\mathrm{Hg}$ from water (mean $=3.767$, CI: 2.777-4.703), whereas the stems demonstrated the weakest ability to accumulate $\mathrm{Hg}$ from sediments (mean $=-1.862$, CI: $-2.503--1.275$ ). Therefore, the trends of the $\mathrm{Hg}$ absorption capacities of the different plant organs were as follows: root $>$ stem $>$ leaf for absorption from water, and root $>$ leaf $>$ stem for absorption from sediments.

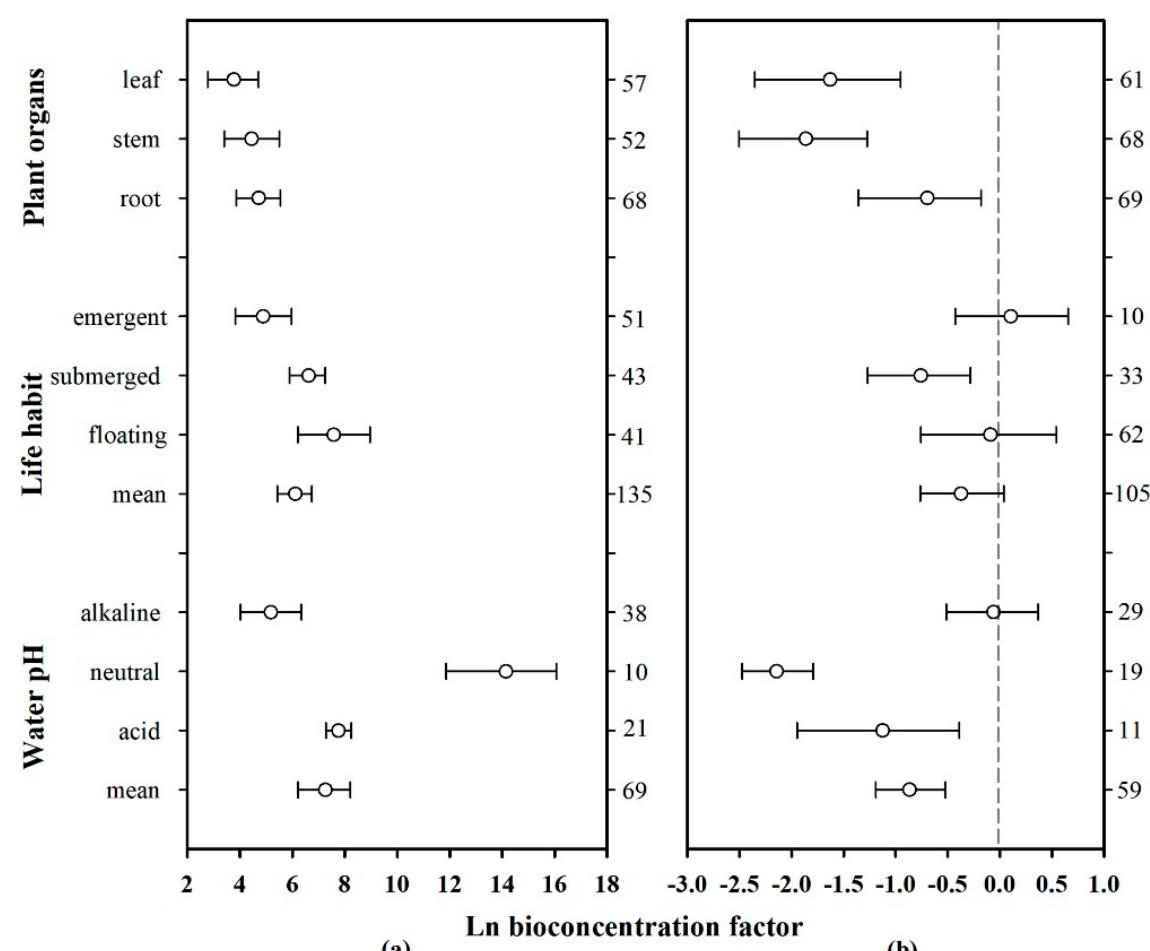

(a)

(b)

Figure 6. Mean biological concentration factor (BCF) values of $\mathrm{Hg}$ in aquatic plants based on $\mathrm{pH}$, life habit, and plant organs. The $\mathrm{pH}$ values were classified as follows: acid (<6.5), neutral (6.5-7.5), and alkaline (>7.5). The error bars represent 95\% bootstrapped CIs, and the numerals on the right $y$-axis represent the number of observations in each category. "Mean" indicates the overall effect considering all the observed plant families. (a) $\mathrm{Hg}$ absorption by plants from water. (b) $\mathrm{Hg}$ absorption by plants from sediments. 
In plants, different organs, such as roots, stems, and leaves, can accumulate different amounts of heavy metals [64,69]. Moreover, some plant species can resist metal toxicity due to the uneven distribution of heavy metals throughout their organs and tissues [64]. As shown in Figure 6 (plant organs), the $\mathrm{Hg}$ concentration in plant organs was significantly higher than that in water, whereas that in the roots was significantly higher than that in the stems and leaves. This result is consistent with the findings of previous studies, which showed that the concentration of heavy metals in the roots is usually higher than that in the stems, leaves, and flowers $[60,70,71]$. This may be because the roots represent the main location where plants absorb heavy metals, and large amounts of $\mathrm{Hg}$ accumulates in sediments that are in direct contact with the plant root (Figure 5). At the same time, the regulation of plant hormones and the synergistic effects of rhizosphere microorganisms can positively promote heavy metal accumulation in the roots [64,72].

\subsubsection{Life Habits}

Based on the field or laboratory environments of aquatic plant growth, aquatic plants can be categorized as floating, submerged, or emergent, depending on their life habits. The effect sizes (ln BCF) of plants of the same family were combined, and the mean and 95\% CI values were determined, after which a forest plot was drawn (Figure 6, life habit). The total average effect size (mean $=6.112, \mathrm{CI}$ : 5.422-6.745) of $\mathrm{Hg}$ absorption from water enriched by different plant types was significantly higher than zero, whereas the total average effect size (mean $=-0.373, \mathrm{CI}:-0.761-0.389$ ) corresponding to $\mathrm{Hg}$ absorbed from the sediments was less than zero. Additionally, the three types of aquatic plants had an $\mathrm{Hg}$ concentration that was significantly higher than that in water. Furthermore, the $\mathrm{Hg}$ concentration in floating and emergent plants was similar to that in sediments, whereas the $\mathrm{Hg}$ concentration in the submerged plants was significantly lower than that in sediments. The absorption effect sizes of different organs of these three types of plants on $\mathrm{Hg}$ in water were further analyzed (Figure 7d). The sample size of various organs of floating plants is small and the credibility is low, but the changing trend of $\mathrm{Hg}$ absorption capacity of different organs of submerged plants and emergent plants is similar to the conclusion in Section 3.4.1.

Previous studies on heavy metal absorption by aquatic plants have shown that plants with different life habits have different heavy metal absorption capacities [73]; this is consistent with the results of this study. However, other studies have shown that the submerged plants have stronger heavy metal absorption capacities than both floating and emergent plants $[74,75]$, and the enrichment mechanism may be related to the plant surface area that is exposed to water. The larger this relative surface area (the surface area-tovolume ratio), the higher the heavy metal uptake rate [76]. As shown in Figure 6a, the $\mathrm{Hg}$ absorption capacities of these three plants with different life habits varied in the order: floating plants $>$ submerged plants $>$ emergent plants. This may be related to the special form of $\mathrm{Hg}$ pollution in nature. Reportedly, $80 \%$ of $\mathrm{Hg}$ in emissions from artificial sources enters the air in gaseous form and then enters water through atmospheric deposition [77]. Plant leaves are not only the receptors for the heavy metals introduced via atmospheric deposition, but they are also effective filters for gaseous heavy metals. Specifically, leaves absorb heavy metals from the atmosphere via stomatal osmosis. Thereafter, the heavy metals are adsorbed and internalized by the stratum corneum or trichomes, followed by storage in the leaf cell wall [78]. With $\mathrm{Hg}$ that has accumulated in sediments as a reference (Figure 6b), the concentration of $\mathrm{Hg}$ absorbed by submerged plants was lower than that by floating and emergent plants in this study, indicating that plant organs in contact with air can absorb $\mathrm{Hg}$ from the surrounding environment (water and air) better than they can from water only. Simultaneously, the analysis showed that floating plant leaves could accumulate substantial amounts of $\mathrm{Hg}$ (Figure 7d). Therefore, floating plants that absorb $\mathrm{Hg}$ from the aquatic environment have the advantage of a maximized surface area in contact with water, while also being able to use their large leaves to absorb gaseous $\mathrm{Hg}$. 


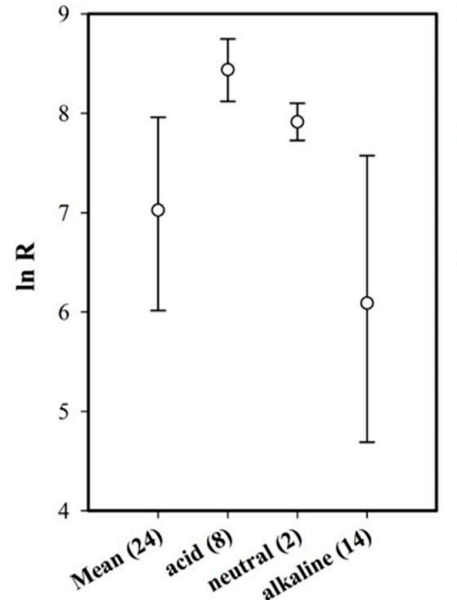

(a)

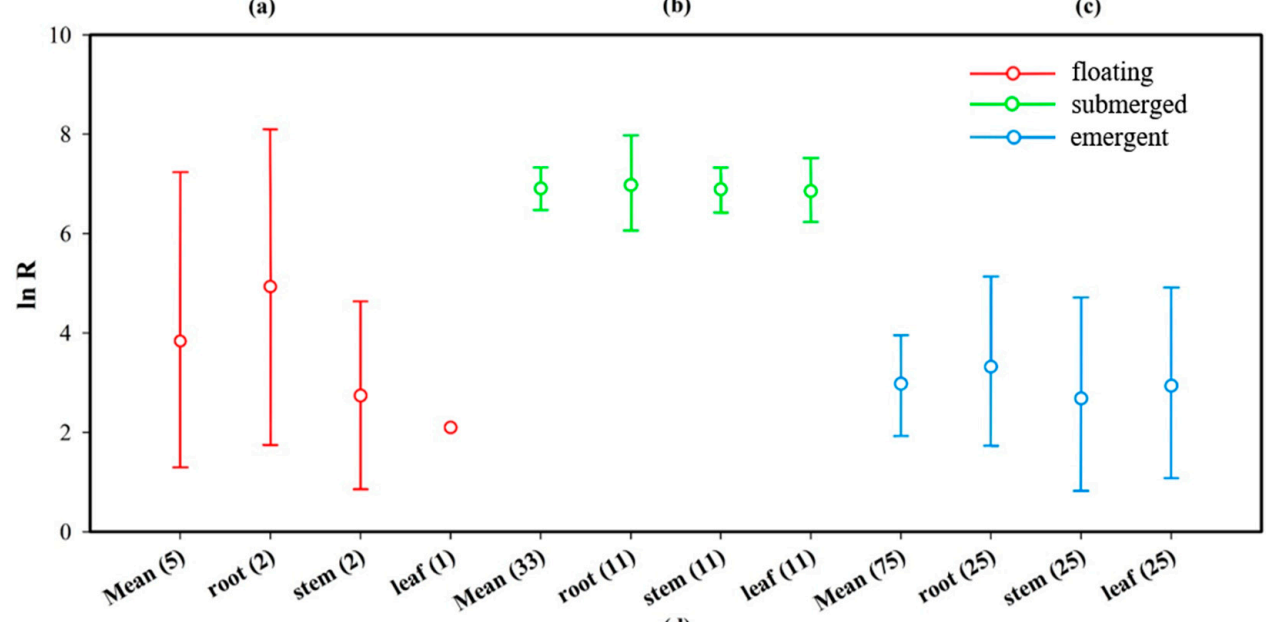

(d)

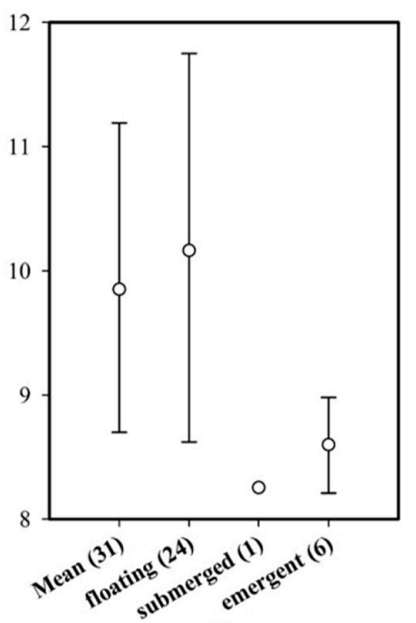

(b)

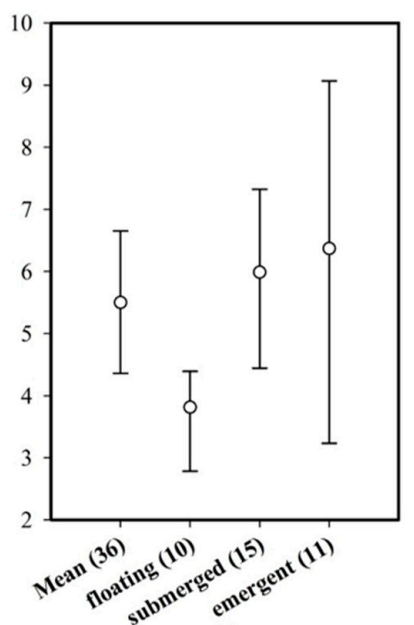

(c)

Figure 7. Mean effect sizes (ln R) of $\mathrm{Hg}$ concentrations in different life habit plants, and plant organs in terms of $\mathrm{pH}$, and life habits. The error bars represent $95 \%$ bootstrapped CIs, and the numerals below the $x$-axis represent the number of observations in each category. "Mean" indicates the overall effect considering all observed objects in the same category. (a) Effect size of $\mathrm{pH}$ on $\mathrm{Hg}$ absorption by plant roots; (b) effect size of life habit on $\mathrm{Hg}$ absorption by plants in neutral and acidic water ( $\mathrm{pH}<7.5)$; (c) effect size of life habit on $\mathrm{Hg}$ absorption by plants in alkaline water $(\mathrm{pH}>7.5)$; and (d) effect size of plant organs on $\mathrm{Hg}$ absorption by different life habit plants.

\subsection{3. $\mathrm{pH}$}

Generally, the $\mathrm{pH}$ of aquatic environments ranges between 5 and 9, with acidity, neutrality, and alkalinity thresholds of $<6.5,6.5-7.5$, and $>7.5$, respectively. The effect sizes (ln BCF) of plants of the same type were combined according to acid-base classification. Thus, the mean and $95 \%$ CI values were calculated, and the corresponding forest plot (Figure 6, water $\mathrm{pH}$ ) was drawn. Under the influence of different $\mathrm{pH}$ conditions, the total average effect size (mean $=7.259, \mathrm{CI}$ : 6.223-8.220) of $\mathrm{Hg}$ in plant-enriched water was significantly higher than zero, whereas that in sediments was significantly lower than zero (mean $=-0.886$, CI: $-1.189-0.523$ ). In neutral environments, the average effect size of $\mathrm{Hg}$ in the plant-enriched water was the highest (mean $=14.144$, CI: 11.837-16.070) compared with that under acidic or alkaline conditions. However, the $\mathrm{Hg}$ concentration in the plants was significantly lower than that in sediments. The average effect size of $\mathrm{Hg}$ uptake by plants in acidic environments (mean $=7.753$, CI: 7.276-8.255) was higher than that in alkaline environments (mean $=5.179$, CI: 4.014-6.345), suggesting that aquatic plants are better suited to absorb $\mathrm{Hg}$ in neutral or slightly acidic environments. Additionally, the $\mathrm{Hg}$ absorption capacity of floating plants was significantly higher than that of submerged plants and emergent plants in environments with $\mathrm{pH}<7.5$ (Figure $7 \mathrm{~b}$ ), but it was opposite in environments with $\mathrm{pH}>7.5$ (Figure 7c). 
$\mathrm{pH}$ is an important factor that influences the ability of plants to absorb heavy metals [79]. The results of this study showed that aquatic plants and sediments accumulated large amounts of $\mathrm{Hg}$ when the $\mathrm{pH}$ was neutral, with the plants exerting the strongest $\mathrm{Hg}$ absorption ability. When the $\mathrm{pH}$ was weakly acidic, the ability of the plants to absorb $\mathrm{Hg}$ was stronger than that observed when the water was weakly alkaline. The $\mathrm{Hg}$ absorption capacity of the roots also showed similar characteristics (Figure 7a). Strong acids and bases affect the normal growth and heavy metal accumulation characteristics of aquatic plants. Conversely, neutral water is beneficial for aquatic plant growth and heavy metal accumulation [80-82]. The absorption of $\mathrm{Hg}$ by sediments from water showed the same trend as that of plants. Under low $\mathrm{pH}$ conditions, the acidification and dissolution of heavy metals is positively affected by the competition between $\mathrm{H}^{+}$in water and organic acids secreted by the plant rhizosphere, which affect the ion exchange process between the metal ions and $\mathrm{H}$ in the functional groups on the cell wall, thus strengthening the absorption and enrichment of heavy metal ions by plants [81]. Fan [83] and Zhang et al. [84] found that the efficiency of heavy metal absorption by Sophora flavescens and aquatic organisms such as Ceratophyllum demersum (goldfish algae) and Myriophyllum spicatum (sargassum) increased with an increase in $\mathrm{pH}$ in acidic environments. However, when the $\mathrm{pH}$ reached 6, the absorption efficiency of some heavy metal ions peaked, but a continuous increase in $\mathrm{pH}$ led to a decrease in the absorption efficiency [83,84]. In this meta-analysis, the effect sizes for $\mathrm{Hg}$ absorption by floating, submerged, and emergent plants in neutral and acidic aquatic environments were $12.739,8.285$, and 9.163, respectively (Figure $7 \mathrm{c}$ ), which are considerably higher than that in water (Figure 6a). Therefore, neutral and slightly acidic aquatic environments are determined as more suitable for the phytoremediation of $\mathrm{Hg}$ pollution than alkaline environments.

\section{Conclusions}

A comprehensive meta-analysis and evaluation of $\mathrm{Hg}$ absorption by aquatic plants showed that the family and life habits of aquatic plants, as well as the water $\mathrm{pH}$, significantly affect the ability of plants to absorb Hg. Based on the published literature, aquatic plant belonging to 17 families, Araceae, Cymodoceaceae, Cyperaceae, Gracilariaceae, Haloragaceae, Hydrocharitaceae, Iridaceae, Juncaceae, Plantaginaceae, Poaceae, Polygonaceae, Pontederiaceae, Posidoniaceae, Potamogetonaceae, Salviniaceae, Typhaceae, and Ulvaceae, have been shown to display significant $\mathrm{Hg}$ absorption capacities. Additionally, aquatic plant roots have a strong capacity for $\mathrm{Hg}$ absorption, and most of the $\mathrm{Hg}$ ions that enter the plants through the roots are stored in the root cell wall, with only a limited proportion being transported upward into the stems and leaves. This study also revealed that the roots of aquatic plants show a superior $\mathrm{Hg}$ absorption capacity compared with the stems, whereas the $\mathrm{Hg}$ absorption capacity of the leaves was lower than that of the stems. Furthermore, the $\mathrm{Hg}$ absorption capacities of plants with different life habits varied in the following order: floating plants > submerged plants > emergent plants. The amount of $\mathrm{Hg}$ absorbed by plants is also significantly affected by the differences in acidity and alkalinity, with aquatic environments with a neutral $\mathrm{pH}$ being the most suitable for $\mathrm{Hg}$ absorption. This study provides a reference for the selection of suitable aquatic plants for phytoremediation with the aim to restore the ecological environment of heavy metal-polluted water.

Author Contributions: Conceptualization, Y.M. and Y.L.; methodology, Y.M.; software, Y.M.; validation, G.W. and Y.W.; formal analysis, Y.M. and G.W.; investigation, W.D. and Y.L.; resources, Y.L. and W.D.; data curation, Y.M. and Y.W.; writing-original draft preparation, Y.M.; writing-review and editing, Y.L. and W.D.; visualization, Y.M.; supervision, Y.L.; project administration, G.W.; funding acquisition, Y.L. All authors have read and agreed to the published version of the manuscript.

Funding: This research was funded by the Fundamental Research Funds for the Central Universities (grant No. 2021ZY14) and the National key Research and Development Program of China (grant No. 2018YFC1801402).

Institutional Review Board Statement: Not applicable. 
Informed Consent Statement: Not applicable.

Acknowledgments: We appreciate the guidance and help of Jingyi Dong, Jing Li, and Zhen Zhang in the process of data analysis.

Conflicts of Interest: The authors declare no conflict of interest. The authors themselves are responsible for the content and writing of the paper.

\section{References}

1. Nyarko, B.J.B.; Dampare, S.B.; Serfor-Armah, Y.; Osae, S.; Adotey, D.; Adomako, D. Biomonitoring in the forest zone of Ghana: The primary results obtained using neutron activation analysis and lichens. Int. J. Environ. Pollut. 2008, 32, 467-476. [CrossRef]

2. Lee, C.S.; Li, X.D.; Shi, W.Z.; Cheung, S.C.; Thornton, I. Metal contamination in urban, suburban, and country park soils of Hong Kong: A study based on GIS and multivariate statistics. Sci. Total Environ. 2006, 356, 45-61. [CrossRef] [PubMed]

3. Ozden, B.; Guler, E.; Vaasma, T.; Horvath, M.; Kiisk, M.; Kovacs, T. Enrichment of naturally occurring radionuclides and trace elements in Yatagan and Yenikoy coal-fired thermal power plants, Turkey. J. Environ. Radioact. 2018, 188, 100-107. [CrossRef]

4. Mason, R.P.; Reinfelder, J.R.; Morel, F.M.M. Bioaccumulation of mercury and methylmercury. Water Air Soil Pollut. 1995, 80, 915-921. [CrossRef]

5. Su, D. Biological Toxicity of five metal ions on marine algea. Appl. Mech. Mater. 2013, 295-298, 17-20. [CrossRef]

6. Weir, P.A.; Hine, C.H. Effects of various metals on behavior of conditioned goldfish. Arch. Environ. Occup. Health 1970, 20 , 45-51. [CrossRef]

7. Kalisinska, E.; Lanocha-Arendarczyk, N.; Podlasinska, J. Current and historical nephric and hepatic mercury concentrations in terrestrial mammals in Poland and other European countries. Sci. Total Environ. 2021, 775, 145808. [CrossRef] [PubMed]

8. Kazantzis, G. Mercury and the kidney. Occup. Med. 1970, 20, 54-59. [CrossRef]

9. Skerfving, S.; Hansson, K.; Lindsten, J. Chromosome breakage in humans exposed to methyl mercury through fish consumption. Preliminary communication. Arch. Environ. Health 1970, 21, 133-139. [CrossRef] [PubMed]

10. Rai, P.K.; Tripathi, B. Heavy metals adsorption characteristics of free floating aquatic macrophyte Spirodela poyrhhiza. J. Environ. Res. Dev. 2007, 5, 656-660.

11. Jackson, L.J. Paradigms of metal accumulation in rooted aquatic vascular plants. Sci. Total Environ. 1998, 219, 223-231. [CrossRef]

12. Bell, A.H.; Scudder, B.C. Mercury accumulation in periphyton of eight river ecosystems 1. J. Am. Water Resour. Assoc. 2007, 43, 957-968. [CrossRef]

13. Romanova, T.E.; Shuvaeva, O.V.; Belchenko, L.A. Phytoextraction of trace elements by water hyacinth in contaminated area of gold mine tailing. Int. J. Phytorem. 2016, 18, 190-194. [CrossRef]

14. Xun, Y.; Feng, L.; Li, Y.; Dong, H. Mercury accumulation plant Cyrtomium macrophyllum and its potential for phytoremediation of mercury polluted sites. Chemosphere 2017, 189, 161-170. [CrossRef]

15. Aladdin, M.; Aziz, F. Response of algae to heavy metal removing with particular reference to pH. Pol. J. Environ. Stud. 2020, 29, 2041-2053. [CrossRef]

16. Zhang, Z.Q.; Bao, M.E.; Chen, J.B.; Hao, H.Y. Tolerance mechanism of plants to heavy metals. Gansu Sci. Technol. 2013, $29,69-71$. (In Chinese) [CrossRef]

17. Gupta, D.K.; Vandenhove, H.; Inouhe, M. Role of phytochelatins in heavy metal stress and detoxification mechanisms in plants. In Heavy Metal Stress in Plants; Gupta, D.K., Corpas, F.J., Palma, J.M., Eds.; Springer: Berlin/Heidelberg, Germany, 2013; pp. 73-94.

18. Li, J.; Yu, H.X.; Luan, Y.N. Meta-analysis of the copper, zinc, and cadmium absorption capacities of aquatic plants in heavy metal-polluted water. Int. J. Environ. Res. Public Health 2015, 12, 14958-14973. [CrossRef]

19. Weatherall, M. Systematic review and meta-analysis: Tools for the information age. Postgrad. Med. J. 2017, 93, 696-703. [CrossRef]

20. Liu, S.; Zhang, Y.; Zong, Y.; Hu, Z.; Wu, S.; Zhou, J.; Jin, Y.; Zou, J. Response of soil carbon dioxide fluxes, soil organic carbon and microbial biomass carbon to biochar amendment: A meta-analysis. GCB Bioenergy 2016, 8, 392-406. [CrossRef]

21. Lenka, M.; Panda, K.K.; Panda, B.B. Monitoring and assessment of mercury pollution in the vicinity of a chloralkali plant. IV. Bioconcentration of mercury in in situ aquatic and terrestrial plants at Ganjam, India. Arch. Environ. Contam. Toxicol. 1992, 22, 195-202. [CrossRef]

22. Gupta, M.; Chandra, P. Bioaccumulation and toxicity of mercury in rooted-submerged macrophyte Vallisneria spiralis. Environ. Pollut. 1998, 103, 327-332. [CrossRef]

23. Ali, M.B.; Vajpayee, P.; Tripathi, R.D. Mercury bioaccumulation induces oxidative stress and toxicity to submerged Macrophyte potamogeton crispus L. Bull. Environ. Contam. Toxicol. 2000, 65, 573-582. [CrossRef] [PubMed]

24. Gothberg, A.; Greger, M. Formation of methyl mercury in an aquatic macrophyte. Chemosphere 2006, 65, 2096-2105. [CrossRef]

25. Isaksson, R.; Balogh, S.J.; Farris, M.A. Accumulation of mercury by the aquatic plant Lemna minor. Int. J. Environ. Stud. 2007, 64, 189-194. [CrossRef]

26. Mishra, V.K.; Upadhyay, A.R.; Pathak, V.; Tripathi, B.D. Phytoremediation of mercury and arsenic from tropical opencast coalmine effluent through naturally occurring aquatic macrophytes. Water Air Soil Pollut. 2008, 192, 303-314. [CrossRef]

27. Castro, R.; Pereira, S.; Lima, A.; Corticeiro, S.; Valega, M.; Pereira, E.; Duarte, A.; Figueira, E. Accumulation, distribution and cellular partitioning of mercury in several halophytes of a contaminated salt marsh. Chemosphere 2009, 76, 1348-1355. [CrossRef] 
28. Mishra, V.K.; Tripathi, B.D.; Kim, K.H. Removal and accumulation of mercury by aquatic macrophytes from an open cast coal mine effluent. J. Hazard. Mater. 2009, 172, 749-754. [CrossRef]

29. Zhang, M.; Cui, L.; Sheng, L.; Wang, Y. Distribution and enrichment of heavy metals among sediments, water body and plants in Hengshuihu Wetland of Northern China. Ecol. Eng. 2009, 35, 563-569. [CrossRef]

30. Ahmad, A.; Ghufran, R.; Zularisam, A.W. Phytosequestration of metals in selected plants growing on a contaminated okhla industrial areas, Okhla, New Delhi, India. Water Air Soil Pollut. 2010, 217, 255-266. [CrossRef]

31. Lafabrie, C.; Major, K.M.; Major, C.S.; Cebrian, J. Arsenic and mercury bioaccumulation in the aquatic plant, Vallisneria neotropicalis. Chemosphere 2011, 82, 1393-1400. [CrossRef]

32. Chattopadhyay, S.; Fimmen, R.L.; Yates, B.J.; Lal, V.; Randall, P. Phytoremediation of mercury and methyl mercury contaminated sediments by water hyacinth (Eichhornia crassipes). Int. J. Phytoremediat. 2012, 14, 142-161. [CrossRef]

33. Tong, Y.; Zhang, W.; Hu, D.; Ou, L.; Hu, X.; Yang, T.; Wei, W.; Ju, L.; Wang, X. Behavior of mercury in an urban river and its accumulation in aquatic plants. Environ. Earth Sci. 2012, 68, 1089-1097. [CrossRef]

34. Bonanno, G. Comparative performance of trace element bioaccumulation and biomonitoring in the plant species Typha domingensis, Phragmites australis and Arundo donax. Ecotoxicol. Environ. Saf. 2013, 97, 124-130. [CrossRef]

35. Miloskovic, A.; Brankovic, S.; Simic, V.; Kovacevic, S.; Cirkovic, M.; Manojlovic, D. The accumulation and distribution of metals in water, sediment, aquatic macrophytes and fishes of the Gruza Reservoir, Serbia. Bull. Environ. Contam. Toxicol. 2013, 90, 563-569. [CrossRef]

36. Gomes, M.V.; Souza, R.R.; Teles, V.S.; Araujo Mendes, E. Phytoremediation of water contaminated with mercury using Typha domingensis in constructed wetland. Chemosphere 2014, 103, 228-233. [CrossRef]

37. Yabanli, M.; Yozukmaz, A.; Sel, F. Heavy metal accumulation in the leaves, stem and root of the invasive submerged macrophyte Myriophyllum spicatum L. (Haloragaceae): An example of Kadin Creek (Mugla, Turkey). Braz. Arch. Biol. Technol. 2014, 57, 434-440. [CrossRef]

38. Branković, S.; Glišić, R.; Topuzović, M.; Marin, M. Uptake of seven metals by two macrophytes species: Potential for phytoaccumulation and phytoremediation. Chem. Ecol. 2015, 31, 583-593. [CrossRef]

39. Gbogbo, F.; Otoo, S.D. The concentrations of five heavy metals in components of an economically important urban coastal wetland in Ghana: Public health and phytoremediation implications. Environ. Monit. Assess. 2015, 187, 655. [CrossRef]

40. Henriques, B.; Rocha, L.S.; Lopes, C.B.; Figueira, P.; Monteiro, R.J.R.; Duarte, A.C.; Pardal, M.A.; Pereira, E. Study on bioaccumulation and biosorption of mercury by living marine macroalgae: Prospecting for a new remediation biotechnology applied to saline waters. Chem. Eng. J. 2015, 281, 759-770. [CrossRef]

41. Romanova, T.E.; Shuvaeva, O.V. Fractionation of mercury in water hyacinth and pondweed from contaminated area of Gold Mine Tailing. Water Air Soil Pollut. 2016, 227, 171. [CrossRef]

42. José, M.N.; Germán, E.M.; José, D.H.; José, P.H.; Díez, S. Removal of mercury from gold mine effluents using Limnocharis flava in constructed wetlands. Chemosphere 2017, 167, 188-192. [CrossRef]

43. Pang, H.J.; Lyu, S.S.; Chen, X.G.; Jin, A.M.; Loh, P.S.; Li, F.; Jiang, Y.; Yang, X.H.; Yan, K.K.; Lou, Z.H. Heavy metal distribution and accumulation in the Spartina alterniflora from the Andong tidal flat, Hangzhou Bay, China. Environ. Earth Sci. 2017, 76, 805-817. [CrossRef]

44. Bonanno, G.; Raccuia, S.A. Comparative assessment of trace element accumulation and bioindication in seagrasses Posidonia oceanica, Cymodocea nodosa and Halophila stipulacea. Mar. Pollut. Bull. 2018, 131, 260-266. [CrossRef]

45. Bonanno, G.; Vymazal, J.; Cirelli, G.L. Translocation, accumulation and bioindication of trace elements in wetland plants. Sci. Total Environ. 2018, 631-632, 252-261. [CrossRef]

46. Casagrande, G.C.R.; dos Reis, C.; Arruda, R.; de Andrade, R.L.T.; Battirola, L.D. Bioaccumulation and biosorption of mercury by Salvinia biloba raddi (Salviniaceae). Water Air Soil Pollut. 2018, 229. [CrossRef]

47. Griboff, J.; Wunderlin, D.A.; Monferran, M.V. Phytofiltration of $\mathrm{As}\left(3^{+}\right), \mathrm{As}\left(5^{+}\right)$, and $\mathrm{Hg}$ by the aquatic macrophyte Potamogeton pusillus L, and its potential use in the treatment of wastewater. Int. J. Phytorem. 2018, 20, 914-921. [CrossRef]

48. He, T.R.; Zeng, L.X.; Xu, Y.Y.; Li, Z.J. Mercury distribution of aquatic plants and its response to mercury in sediments in Caohai wetland, Guizhou Province. Chin. J. Ecol. 2018, 37, 793-800. (In Chinese) [CrossRef]

49. Xu, S.Y.; Hu, Q.Y.; Dong, H.Y.; Wang, Q.; Ding, W.; Zhang, S.; Wu, S.C.; Liang, P. Mercury accumulation in five different aquatic plants. J. Zhejiang AEF Univ. 2018, 35, 785-793. (In Chinese) [CrossRef]

50. Napaldet, J.T.; Buot, I.E. Absorption of lead and mercury in dominant aquatic macrophytes of Balili River and its implication to phytoremediation of water bodies. Trop. Life Sci. Res. 2020, 31, 19-32. [CrossRef] [PubMed]

51. Hozo, S.P.; Djulbegovic, B.; Hozo, I. Estimating the mean and variance from the median, range, and the size of a sample. BMC Med. Res. Methodol. 2005, 5, 13. [CrossRef]

52. Hedges, L.V.; Gurevitch, J.; Curtis, P.S. The meta-analysis of response ratios in experimental ecology. Ecology 1999, 80, 1150-1156. [CrossRef]

53. Adams, D.C.; Gurevitch, J.; Rosenberg, M.S. Resampling tests for meta-analysis of ecological data. Ecology 1997, 78, 1277-1283. [CrossRef]

54. Rosenberg, M.S.; Adams, D.C.; Gurevitch, J. Metawin: Statistical Software for Meta-Analysis with Resampling Tests; Sinauer Associates: Sunderland, MA, USA, 1997; p. 65. 
55. Gurevitch, J.; Hedges, L.V. Meta-Analysis: Combining the Results of Independent Experiments, 2nd ed.; Oxford University Press: Oxford, UK, 2001; pp. 347-370.

56. Sterne, J.A.; Gavaghan, D.; Egger, M. Publication and related bias in meta-analysis: Power of statistical tests and prevalence in the literature. J. Chronic Epi. 2000, 53, 1119-1129. [CrossRef]

57. Stuck, A.E.; Rubenstein, L.Z.; Wieland, D. Bias in meta-analysis detected by a simple, graphical test. Asymmetry detected in funnel plot was probably due to true heterogeneity. BMJ 1998, 316, 469. [CrossRef]

58. Sharma, P.; Dubey, R.S. Lead toxicity in plants. Braz. J. Plant Physiol. 2005, 17, 35-52. [CrossRef]

59. Xu, C.X. Studies on Mechanism of Heavy Metals in Water on Ornament Aquatic Plants \& Technology of Tissue Culture. Master's Thesis, Nanjing Forestry University, Nanjing, China, 2005. (In Chinese).

60. Sharma, S.S.; Gaur, J.P. Potential of Lemna polyrrhiza for removal of heavy metals. Ecol. Eng. 1995, 4, 37-43. [CrossRef]

61. Jones, D.L.; Darah, P.R.; Kochian, L.V. Critical evaluation of organic acid mediated iron dissolution in the rhizosphere and its potential role in root iron uptake. Plant Soil 1996, 180, 57-66. [CrossRef]

62. Zaranyika, M.F.; Mudungwe, L.; Gurira, R.C. Cyanide ion concentration in the effluent from two gold mines in Zimbabwe and in a stream receiving effluent from one of the goldmines. J. Environ. Sci. Health Part A Environ. Sci. Eng. Toxic Hazard. Subst. Control 1994, 29, 1295-1303. [CrossRef]

63. Greger, M. Metal availability and bioconcentration in plants. In Heavy Metal Stress in Plants: From Molecules to Ecosystems; Springer: Berlin/Heidelberg, Germany, 1999; pp. 1-27.

64. Mahmood, Q.; Mirza, N.; Shaheen, S. Phytoremediation Using Algae and Macrophytes: I. In Phytoremediation: Management of Environmental Contaminants; Ansari, A.A., Gill, S.S., Gill, R., Lanza, G.R., Newman, L., Eds.; Springer International Publishing: Cham, Switzerland, 2015; Volume 2, pp. 265-289.

65. Salt, D.E.; Blaylock, M.; Kumar, N.P.B.A.; Dushenkov, V.; Ensley, B.D.; Chet, I.; Raskin, I. Phytoremediation: A novel strategy for the removal of toxic metals from the environment using plants. Bio/Technology 1995, 13, 468-474. [CrossRef]

66. Schwab, F.; Zhai, G.; Kern, M.; Turner, A.; Schnoor, J.L.; Wiesner, M.R. Barriers, pathways and processes for uptake, translocation and accumulation of nanomaterials in plants-Critical review. Nanotoxicology 2016, 10, 257-278. [CrossRef]

67. Chaney, R.L.; Malik, M.; Li, Y.M.; Brown, S.L.; Brewer, E.P.; Angle, J.S.; Baker, A.J.M. Phytoremediation of soil metals. Curr. Opin. Biotechnol. 1997, 8, 279-284. [CrossRef]

68. Veglio, F.; Beolchini, F. Removal of metals by biosorption: A review. Hydrometallurgy 1997, 44, 301-316. [CrossRef]

69. Pospíšilová, J.; Huang, B. (Eds.) Plant-Environment Interactions, 3rd ed.; Wiley Online Library: Hoboken, NJ, USA, 2021 ; Volume 2.

70. Ashraf, M.A.; Maah, M.J.; Yusoff, I. Heavy metals accumulation in plants growing in ex tin mining catchment. Int. J. Environ. Sci. Technol. 2011, 8, 401-416. [CrossRef]

71. Akhtar, M.; Sarwar, N.; Ashraf, A.; Ejaz, A.; Ali, S.; Rizwan, M. Beneficial role of Azolla sp. in paddy soils and their use as bioremediators in polluted aqueous environments: Implications and future perspectives. Arch. Agron. Soil Sci. 2020, 67, 1242-1255. [CrossRef]

72. Lucini, L.; Colla, G.; Miras Moreno, M.B.; Bernardo, L.; Cardarelli, M.; Terzi, V.; Bonini, P.; Rouphael, Y. Inoculation of Rhizoglomus irregulare or Trichoderma atroviride differentially modulates metabolite profiling of wheat root exudates. Phytochemistry 2019, 157, 158-167. [CrossRef]

73. Li, J.; Luan, Y.N.; Sun, X.Y.; Yu, H.X.; Qi, N.; Wu, X.Y. Research advance in remediation of heavy metal contaminated water bodies by aquatic plants. World For. Res. 2015, 28, 31-35. (In Chinese) [CrossRef]

74. Albers, P.H.; Camardese, M.B. Effects of acidification on metal accumulation by aquatic plants and invertebrates. 2. Wetlands, ponds and small lakes. Environ. Toxicol. Chem. 1993, 12, 969-976. [CrossRef]

75. Yurukova, L.; Kochev, K. Heavy metal concentrations in freshwater macrophytes from the Aldomirovsko swamp in the Sofia District, Bulgaria. Bull. Environ. Contam. Toxicol. 1994, 52, 627-632. [CrossRef]

76. Rai, U.N.; Sinha, S.; Tripathi, R.D.; Chandra, P. Wastewater treatability potential of some aquatic macrophytes: Removal of heavy metals. Ecol. Eng. 1995, 5, 5-12. [CrossRef]

77. Futsaeter, G.; Wilson, S. The UNEP global mercury assessment: Sources, emissions and transport. E3S Web Conf. $2013,1,36001$. [CrossRef]

78. Shahid, M.; Dumat, C.; Khalid, S.; Schreck, E.; Xiong, T.; Niazi, N.K. Foliar heavy metal uptake, toxicity and detoxification in plants: A comparison of foliar and root metal uptake. J. Hazard. Mater. 2017, 325, 36-58. [CrossRef] [PubMed]

79. Chen, H.M.; Zheng, C.R.; Tu, C.; Shen, Z.G. Chemical methods and phytoremediation of soil contaminated with heavy metals. Chemosphere 2000, 41, 229-234. [CrossRef]

80. Pan, C.L.; He, J. Effect of hydrophyte on treatment of wastewater with chromium. Environ. Sci. Sur. 2006, 25, 34-35. (In Chinese) [CrossRef]

81. Brady, D.; Duncan, J.R. Bioaccumulation of metal cations by Saccharomyces cerevisiae. Appl. Microbiol. Biotechnol. 1994, 41, 149-154. [CrossRef]

82. Zhao, Y.; Wang, Y.; Wang, T.; Zhu, B. Screening for high nitrogen and phosphorus enrichment ditch plants in the Hilly Area of Central Sichuan Basin. Environ. Pollut. Control 2015, 37, 12-16. (In Chinese) [CrossRef] 
83. Fan, C.C. The Biological Adsorption Effect Research of Rat Tail Algae on Heavy Metals Lead, Copper, Zinc and Cadmium in Water. Master's Thesis, Zhejiang Ocean University, Zhoushan, China, 2013. (In Chinese)

84. Zhang, Y.J.; Yi, M.; Wang, C.; Dong, Y.; Liu, X.P.; Wen, X.F.; Li, Y. Research on phytoremediation of cadmium contaminated water by three submerged macrophytes. J. Shanghai Ocean Univ. 2012, 21, 784-793. (In Chinese) 